Lectio

\title{
Ennen saatuja sanoja: Kalevalamittainen runolaulu, nykykansanmusiikki ja perinne
}

\author{
Lectio praecursoria Helsingin yliopistossa 13.1.2017
}

Heidi Haapoja

Kalevalamittainen runolaulu on Suomessa kansallissymboliaseman saavuttanut ilmaisumuoto, jolla on juuret useamman tuhannen vuoden takana. Itämerensuomalaisella alueella esiintyvää kahdeksantavuista runomittaa kutsutaan Suomessa usein kalevalamitaksi, koska Elias Lönnrot perusti Kalevala-eepoksensa sen varaan. Kalevala on kuitenkin vain pieni osa kalevalamittaisten runojen merta: alun perin laulettuina kulkeneita runoja on tallennettu itämerensuomalaisella alueella valtavia määriä. Näissä merkityksellisissä lauletuissa runoissa kiteytyivät yhteisön tiedot, taidot ja uskomukset, ja runot liikkuivat suullisesti ihmiseltä toiselle alati hienovaraisesti muuttuen ja kontekstiinsa sopeutuen.

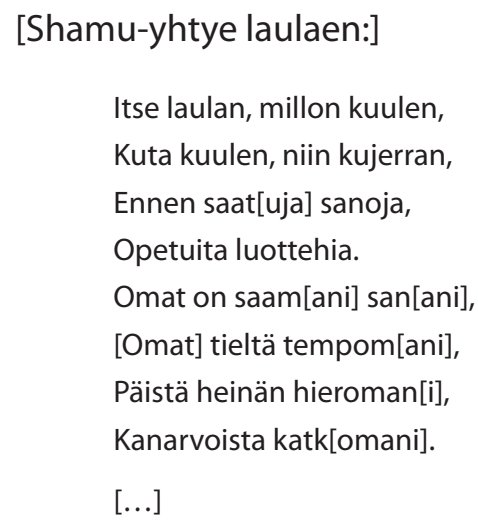

(SKVR I3, 1278. Latvaj. Lönnrot A II 6, n. 100. 34. Arhippa Perttuńe.)

1800-luvun aikana, kun eurooppalaisen kansallisromantiikan henki oli saavuttanut suomenja ruotsinkielisen eliitin, alempien yhteiskuntaluokkien keskuudessa kulkeneet runot huomattiin ja ikään kuin löydettiin kansan pariin suuntautuneilla kenttäretkillä. Filosofi Johan Gottfried Herderin hengessä ajateltiin, että kansanrunous oli merkittävä vaihe tietoisuuden ja ihmisyyden kehityksessä, ja kansanlaulut nähtiin sivistymättömän, aistillisen kansan hengenilmaisuna. Laulujen löytämisen myötä ne myös muuttivat olomuotoaan: niistä alettiin tehdä kirjallisia muistiinpanoja, nuotinnoksia, kirjajulkaisuja ja näiden vanavedessä syntyi myös kansalliseepos, Kalevala, jonka myötä kalevalamittaiseen runouteen liittyvää suomalaisuus-eetosta on toistettu yhä uudelleen ja uudelleen. 


\section{Nykykansanmusiikin synty}

1960-luvulla, kun suomalaista yhteiskuntaa leimasi voimakas teollistuminen ja kaupungistuminen, moniaalla länsimaissa ja toisaalta myös Neuvostoliitossa oli herännyt nostalgiaa henkivä innostus menetetyiksi, aidoiksi ja hektisen modernisaation ikeestä puhtaiksi ajateltuja kansanlauluja ja kansanmusiikkia kohtaan. Näin kävi myös Suomessa, jossa ihailtiin erityisesti maaseutukulttuuria, ja tämän myötä Suomessa alettiin elvyttää instrumenttipohjaista, maaseudun miesten suosimaa pelimannimusiikkia. Syntyi Kaustisen kansanmusiikkijuhlat ja suuri määrä harrastajaorganisaatioita.

Soitinpohjainen pelimannimusiikki ei kuitenkaan tarjonnut kaikille viehätystä: haluttiin jotakin vielä muinaisempaa, vielä arkaaisempaa. Tästä syystä korkeasti koulutettujen, usein varsin liberaalien ja kaupunkilaistuneiden musiikintutkijoiden joukossa syntyi 1970-luvulla muinaismusiikki-innostus, joka johti kalevalamittaisten runolaulujen esiin nostamiseen ja valtavien arkistomateriaalien käyttämiseen avantgardistisen, taiteellisesti kunnianhimoisen musisoinnin taustana. 1980-luvulle tultaessa tämä johti siihen, että maan ainoaan musiikkiyliopistoon Sibelius-Akatemiaan perustettiin kansanmusiikin osasto. Tästä alkoi kansanmusiikin ammattilaistuminen, ja tätä nykykansanmusiikiksi kutsuttua ammattimaisen musiikintekemisen kenttää tutkin väitöskirjassani.

1990-luvulta alkaen kalevalamittainen runolaulu on ollut merkittävä osa suomalaista nykykansanmusiikkia. Moni ehkä muistaa Värttinä-yhtyeen ja sen suuren suosion, ja 2000-luvun aikana kalevalamittaista runolaulua on kuultu niin Musiikkitalon suurella lavalla, sinfoniaorkesterien levyillä, klubeilla, festivaaleilla kuin pienimuotoisissa taidetapahtumissakin. Nykykansanmusiikin puitteissa runolaulujen taustana käytetään vanhoja arkistoäänitteitä ja runotekstejä, mutta niitä ei pyritä rekonstruoimaan, vaan käyttämään taiteellisen ilmaisun

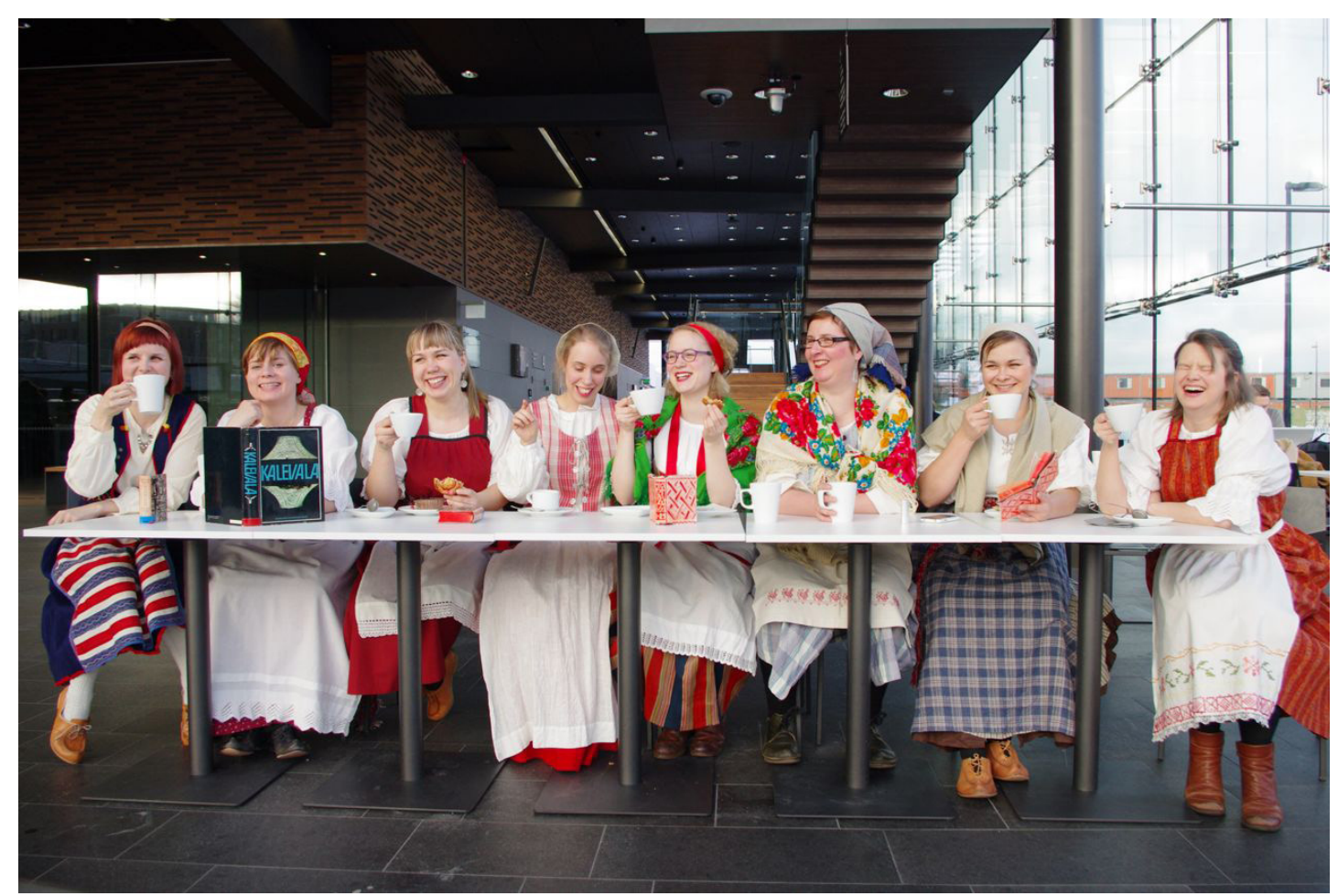

Kuva 1. Shamu-yhtye Musiikkitalon kahvilassa vuonna 2013. Kuva: Taavi Tatsi. 
väylänä. Muusikot pyrkivät sisäistämään runolaulut ja tekemään niistä "omia", mutta samalla säkeissä koetaan limittyvän monien menneiden laulajien äänet ja historiat.

\section{Nimeämisen prosessissa syntyvä perinne}

Väitöskirjassani kysyin, miten runolauluun liittyvässä puheessa rakennetaan menneisyyden ja nykyisyyden suhde. Aineistossa suhde rakentuu monin tavoin: henkilökohtaisella, kansallisella, esitysten ja kulttuurisen liikkeen tasolla. Kulttuurisen liikkeen ja välittymisen tasolla tuo suhde muodostetaan runolaulun nimeämisessä perinteeksi. Käsittelen lectiossani tätä nimeämisen prosessia.

Yleiskielessä perinne-käsitettä käytetään kuvaamaan tapojen ja uskomusten periytymistä ja liikettä ajassa, mikä jo itsessään luo jatkumosuhteen nykyisyyden ja menneisyyden välille. Perinne nähdään usein jonakin, joka on ei-kirjallista ja suullista, periytyvää ja vanhaa sekä arvostettua. Äkkiseltään ajateltuna kalevalamittainen runolaulu onkin kaikkea tätä, mutta tarkemmin tarkasteltuna nämä määreet alkavat vaikuttaa hankalilta: mitä oikeastaan tarkoittaa ei-kirjallinen ja suullinen? Millä tavalla perinne periytyy ja kuinka vanhaa sen täytyy olla? Kuka määrittää perinteen arvon ja miksi? Kun kalevalamittainen runolaulu asetetaan nykykansanmusiikin kontekstiin, millaisessa valossa nämä määreet silloin näyttäytyvät?

Tutkimuksessani etsin näihin kysymyksiin vastausta aineistostani, muusikoiden haastatteluista ja mediateksteistä, sillä halusin tietää, miten aineistossa perinne määritellään ja nimetään. Teoreettinen tausta-ajatus tälle näkökulmalle nousee tavasta nähdä perinne jonakin, joka ei ole sisäsyntyisesti asioihin liittyvä tekijä. Mikään asia tai kulttuurimuoto ei siis ole perinnettä tai perinteinen, ennen kuin se sellaiseksi sanoitetaan. Tästä perspektiivistä katsoen perinne tuotetaan nimeämisen prosesseissa asioihin yhä uudelleen ja uudelleen, ja tässä nimeämisen prosessissa syntyy kulttuurista liikettä. Tämä ei kuitenkaan ole mitä tahansa liikettä: kuten edesmennyt akateemikko Anna-Leena Siikala toteaa, "Menneisyydestä nykyisyydessä, toisin sanoen perinteestä, tulee perinnettä, kun linkki nykyisyyden ja etnisesti tai kansallisesti relevantin menneisyyden välillä nähdään merkittävänä." Kalevalamittainen runolaulu on tästä eräänlainen oppikirjaesimerkki: sitä ei tuoteta perinteeksi vain nykykansanmusiikin kentällä, vaan laajasti yhteiskunnallisissa ja julkisissa diskursseissa. Suomessa runolaulujen on ajateltu kantavan mukanaan kansallisesti relevantteja menneisyyden ääniä, historioita ja tulkintoja jo usean vuosisadan ajan.

\section{Runolaulu on perinnettä, mutta miten?}

Kalevalamittainen runolaulu nimetään aineistossani perinteeksi ainakin kahdella tavalla. Ensinnäkin, perinne tarkoittaa aineistossa runolaulun välittymisen prosessia. Runolaulun tapauksessa perinteiseksi välittymisen tavaksi ymmärretään useimmiten suullinen muoto, siis laulujen välittyminen laulajalta toiselle muistinvaraisesti ei-moderniksi ymmärretyssä perinneyhteisössä. Tällainen perinteen välittymisen prosessi nähdään aineistossa ensisijaisesti kuolleena, menetettynä ja nykyisen modernin maailman hävittämänä. Välittymisen prosessissa kuvataan tapahtuneen katkos, joka erottaa nykyisen ajan ja nykyiset laulut menneestä. Tätä ei välttämättä kuitenkaan nähdä onnettomana asiana: vaikka runolauluperinteen välittymisen suullinen muoto nähdään kuolleena, on sen tilalle tullut uudenlainen, kirjallinen ja nykymaailmaan soveltuva tapa välittää runolauluja. Katkos perinteessä antaa vapaat kädet "katsoa" lauluja uusin silmin, kuten laulaja Outi Pulkkinen kuvaa haastattelussa: 


\begin{abstract}
H: Sä puhuit, että siinä sun äidin ikäpolven tienoilla on tullu katkos, tai äidin ja isoäidin välissä. Onks sun mielest tässä runolaulussa tapahtunu semmonen katkos?

O: Kyllä joo, ihan totaalinen katkos. Vienan Karjalassa nyt vissiin ehkä joitaki ihmisiä on elossa, mitkä on omilta vanhemmiltaa tai sukulaisiltaan oppinu niitä [runolauluja]. Ei se elävänä siellä kuitenkaan enää oo.

H: Et me tavallaan katellaan niitä arkistoaineistoja semmosen katkoksen yli?

O: Kyllä.

H: Mitä sä ajattelet et se katkos merkkaa siinä välissä?

O: No, se varmaan on ollu jollain lailla väistämätön. Justiisa tää nopeen tiedonkulun, musiikillisten virtausten ja en tiiä, ehkä jonkun [nauraa] suomalaisen itsetunnon puutteen takia tullu. Mutta tuota, toisaalta se varmaan siihen tekee ihan erilaisen jutun, ku että jos me oltas eletty siinä runolaulumaailmassa. [...] Jos ei olis sitä katkosta, niin eri tavalla katottas niitä arkistoja. Et meil ei ehkä olis noita arkistoäänitteitä, jossei sitte ois tullu tätä katkosta.
\end{abstract}

(OP/HH13052011)

Esimerkissä suullisen välittymisen prosessissa nähdään "totaalinen katkos", mikä on tyypillistä runolauluun liittyvälle puheelle. Ajatus juontaa juurensa niin kutsuttuun modernisaatiokertomukseen, jossa historiallinen tietoisuus on kahtiajakautunut. Modernisaatiokertomuksessa vastakkain asettuvat moderni ja traditionaali aika, ja jälkimmäinen nähdään tällöin menetettynä ja modernin tuhoamana. Samalla tuo menetetty traditionaalinen aika näyttäytyy ikään kuin puhtaampana, pysähtyneempänä, rauhaisampana, myyttisempänä ja vähemmän hektisenä kuin nykyinen. Nykyisyydestä käsin tuohon menetettyyn aikaan on helppo kaivata.

Modernisaatiokertomuksen kahtiajakautuneen ajan ajatus on nähtävissä myös seuraavassa Helsingin Sanomissa julkaistussa Värttinä-yhtyeen Vienan-Karjalan matkaa ja levyä koskevassa haastattelussa vuodelta 2015. Luen esimerkin:

\begin{abstract}
Vieläkö runonlauluperinne elää kylissä vahvana? "Kyllä se on katoamassa. Laulaminen ei ole itsestään selvästi siellä enää tätä päivää. Osa laulajista oli jo kovin vanhoja. Eräälläkin mummolla oli niin paha astma, ettei ääni kulkenut. Hänellä oli surullinen päivä sinä päivänä. Ei oikein laulattanut. Toiselle taas aikamiespoika huuteli toisesta kamarista, että älähän nyt laula mummo siellä. Oli siellä siis karuuttakin nähtävissä. Mutta monella kyllä muisti pelasi vielä. Tarinoita nuoruusajasta ja vanhoja lauluja riitti. Oli myös hieno huomata, että perinne elää kuitenkin nuorempien keskuudessa. Tapasimme muutaman kuoron, jotka ovat opetelleet näitä kappaleita ja vievät perinnettä eteenpäin."
\end{abstract}

Esimerkissä on nähtävissä viittaus ajatukseen, jossa perinteen välittymisen prosessi nähdään hiipuvana ja katoamaisillaan olevana. Samaan aikaan esimerkissä mainitaan kuitenkin hivenen paradoksaalisesti, että "perinne elää nuorempien keskuudessa". Tässä kohdin kaksi erilaista perinnekäsitystä leikkaavat toisensa: jos suullisen välittymisen prosessi nähdään kuolevana, viittaa tässä "elävä perinne" toisenlaiseen tapaan ymmärtää perinteen käsite.

Tässä näkemyksessä huomio siirtyy välittymisen prosessista sisältöön, joka välittyy. Perinne tarkoittaa tällöin itse laulua, melodiaa, runomittaa, säkeitä ja niistä muodostunutta tarinaa. Tällöin suullinen välittyminen siirtyy taka-alalle, ja runolaulun sisältö asettuu keskiöön. Aineistossa laulun sisällön matka menneisyydestä kohti nykyisyyttä nähdään katkeamattomana ketjuna, vaikka laulun kontekstit ja tulkinnat ovatkin erilaisia. Perinnettä voidaan näin ollen opetella ja opiskella kirjoista ja arkistoista, kuten Värttinän laulaja Karoliina Kantelinen kuvailee haastattelussa: 

H: Jos sä aattelet vaikka sitä 1800-luvun runolaulukulttuuria [...], ni mimmosen yhteyden sä näät siinä
runolaulajien välillä? Tai runolaulukulttuurin välillä?

K: Näämmä siin sellasen yhtäläisyyden. No, sanotaan ensin se eroavaisuus, että kun tosiaan se konteksti on eri, et meillä se on esittävää taidetta, opiskeltavaa lajia, ni sillon se on ollu sitä iha arkielämää. Se on ollu arkea ja pyhyyttä yhtä aikaa. Laulaja on kuitenki aina laulaja, se rakastaa sitä, mitä se tekee. Ni kyl mä koen, et nyt tässä päivässä myös se intohimo välittää niit tarinoita, ni se on jatkunu sielt hamast. Et ne menee sinne vuoteen miinus nolla. Että ihminenhän vaan haluu kertoa juttuja, ja sit ku se on löytäny sen sanallisen ja musiikillisen muodon, niin se on kyllä aika hurjaa, et jos semmonen joskus katkee. Et mikä voi olla niin hurja tapahtuma, että ihminen ei enää kerro eikä laula tarinoita? Ja vaikka ei oo sanojakaan, ni kylhän se tarina on siin melodiassa. Niin ne samat, ne laulajat. Et se on ollu se laulu, tai musiikki on ollu siinä koko ajan ihmisen lähellä, et nyt se on erotettu. Mutta ehkä se on se sana, se on se tarina, joka on ollu se katkeamaton meidän laulajien välillä. Ja sit ku se tarina siirtyy, vaik ne on vaan siel arkistonauhas, tai sit ne mitä on kerätty, meil on ne kirjallisena siinä, ni kuitenki sä näät sen tarinan siinä. Ni sitten nykyihminen pystyy sen nappaamaan ja kertoo sen taas joko juuri niin tai sit omin sanoin. Et kuitenki se tarina elää.

(KK/HH06952014)

Haastattelukatkelmassa perinne eli "sana" nimetään ja tehdään katkeamattomaksi. Runolaulu juurrutetaan osaksi muinaisuudesta kumpuavaa inhimillistä tarvetta kertoa tarinoita, eikä tarinoiden välittymisen tavalla loppujen lopuksi ole kovin suurta merkitystä tässä yhteydessä.

\section{Niin sain sanoa saatu}

Alussa lauloimme laulajan aloitussanat, jotka Elias Lönnrot tallensi vuonna 1834 vienalaiselta Arhippa Perttuselta. Myös näissä säkeissä kommentoidaan perinteen olemusta, sitä, kuinka laulu välittyy ja siirtyy laulajalle. Sanat eli laulu olivat Perttusen vienalaisyhteisössä auktoriteetteja, jotka kantoivat mukanaan perinteellistä tietoa ja viisautta. Sanat olivat ennen saatuja, siis mennyttä nykyisyydessä, perinnettä. Mielenkiintoista kyllä, silti Perttunen, suullisessa runolaulukulttuurissa elänyt taitava laulaja, ei kertonut oppineensa lauluja suullisen välittymisen ketjussa esimerkiksi suvulta, vanhemmilta tai muulta nimetyltä lähteeltä. Ei, laulussaan laulava minä korostaa oppineensa laulut itse - omat on saamani sanani, hän sanoo.

Noissa muutamissa Perttusen ääntä haaleina kaikuina kantavissa säkeissä on yllättävän paljon samaa kuin oman aineistoni laulajien kommenteissa omasta perinteeseen kiinnittymisestään: vaikka perinne sanojen eli laulun merkityksessä nähdään katkeamattomana, eräänlaisena ajan läpi kulkevana itsenäisenä subjektina, pitää perinne silti tehdä omaksi, opetella itse.

[Shamu-yhtye laulaen:]

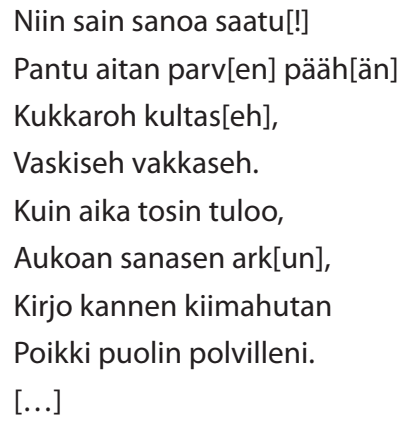


Perttusen laulussa perinteen kerrotaan olevan tallessa säiliössä, sanaisessa arkussa, kunnes se sieltä taas haetaan. Raotimmeko mekin tuota arkkua tänään, vaikka olemmekin monella tavalla Perttusen perinneyhteisön toisia, ulkopuolisia, 2000-luvun suomenkielisinä kaupunkilaisina? Jotakin merkityksellistä ja relevanttia noiden säkeiden on kannettava mukanaan, sillä muuten kukaan meistä ei olisi täällä tänään kokoontuneena näiden sanojen äärelle. Tämä merkityssuhde jää lopulta jokaisen laulajan ja kuulijan itsensä harkittavaksi, mutta omassa tutkimuksessani haastateltujen laulajien vastaus on selvä: jokainen kalevalamittaisen runolaulun esitys tuotetaan ja kytketään monin säikein osaksi katkeamattomien sanojen ketjua, perinnettä.

Haapoja, Heidi 2017: Ennen saatuja sanoja. Menneisyys, nykyisyys ja kalevalamittainen runolaulu nykykansanmusiikin kentällä. Suomen Etnomusikologisen Seuran julkaisuja 22. http://julkaisut.etnomusikologia.fi/julkaisut/Haapoja_Heidi_Ennen_Saatuja_ Sanoja 2017.pdf

Filosofian tohtori, musiikin maisteri Heidi Haapoja toimii post doc -tutkijana Helsingin yliopistossa Koneen säätiön rahoittamassa "Omistajuus, kieli, kulttuuriperintö: Kansanrunousideologiat Suomen, Karjalan tasavallan ja Viron alueilla" -projektissa. 